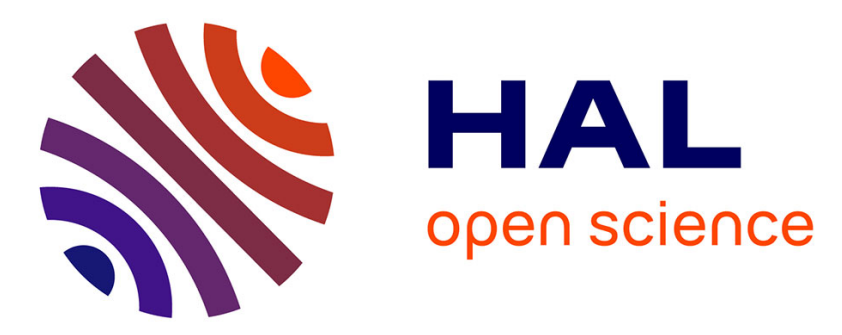

\title{
The Effect of Foreign Direct Investment in Information and Communication Technology in Developing Countries -The Case of Sultanate of Oman
}

Naser Alraja

\section{- To cite this version:}

Naser Alraja. The Effect of Foreign Direct Investment in Information and Communication Technology in Developing Countries - The Case of Sultanate of Oman. International Journal of Economic Performance ,2018 01 (01). hal-03455847

\section{HAL Id: hal-03455847 https://hal.science/hal-03455847}

Submitted on 29 Nov 2021

HAL is a multi-disciplinary open access archive for the deposit and dissemination of scientific research documents, whether they are published or not. The documents may come from teaching and research institutions in France or abroad, or from public or private research centers.
L'archive ouverte pluridisciplinaire HAL, est destinée au dépôt et à la diffusion de documents scientifiques de niveau recherche, publiés ou non, émanant des établissements d'enseignement et de recherche français ou étrangers, des laboratoires publics ou privés. 


\title{
The Effect of Foreign Direct Investment in Information and Communication Technology in Developing Countries -The Case of Sultanate of Oman-
}

\author{
Pr. Mansour Naser ALRAJA \\ malraja@du.edu.om \\ Department of Management Information Systems, Dhofar University
}

\begin{abstract}
One of the main areas in developing the economy of any country is the planning of the foreign direct investment (FDI) to be employed in a proper manner as a very crucial tool in development. FDI has many effects; and one of them is flourishing the ICT sector as a vital sector which includes four sub-sectors according to the World Bank (High-Technology Exports, ICT Goods Exports, ICT Goods Imports, ICT Service Exports).

The authors try to test the effect of FDI on flourishing ICT sub-sectors as one of the drivers of economy development, the proper employment of FDI is an echo of healthy, well planning of it. The results show that there is ad-hoc planning of FDI and there should be a clearer view of how to exploit FDI in economy development and especially in ICT.
\end{abstract}

\section{Keywords}

Foreign direct investment (FDI), ICT, High-Technology Exports, ICT Goods Exports, ICT Service Exports, ICT Goods Imports, Oman. 


\section{Introduction}

Initially, FDI (Foreign Direct Investment) is considered as an arguable issue which is promoted by the World Bank and IMF as an indicator for good investment (Farrell, 2004), it is reflectedas amethod of capital inflows for developing countries. It directly contributes to capital stocks to achieve growth through different channels (Gulde, Kähkönen, \& Keller, 2000).

On the other hand; investment in technology is vital for any economy (Campos \& Kinoshita, 2002) and technology transfer can be effected widely by FDI if the developing countries apply incorporate arrangements that drive this transfer the right context (Blomström \& Sjöholm, 1999).

\section{Literature Review}

(Srinivasan, Kalaivani, \& Ibrahim, 2011) argued that; in the era that we are living, foreign direct investment is considered as a vital factor for the economic growth of countries, particularly of developing countries, that's for many reasons including but not limited to transfer of capital and technology(Chaudhry, Mehmood, \& Mehmood, 2013). Many studies in economic literature have analyzed the relationship between foreign direct investment and economic growth (Alam, 2013)(Mishal \& Abulaila, 2007). In general, foreign direct investment lead to capital density which it has an effect on labor productivity growth (Vukšić, 2016), this result agreed with the report findings of International Monetary Fund (IMF) prepared for Croatia (IMF, 2012). From total productivity perspective, the study of (Demir \& Su, 2016) indicated that foreign investors face higher entry barriers, and they respond strongly to total productivity levels in the past. The estimation results using generalized method of moments (GMM) in china show that the inflow of foreign direct investment, lead to worsen the income inequality, and there was non-linear effect of the inflow of foreign direct investment on income inequality (Mah, 2015). In the same line (Figini \& Görg, 2011) suggested that over the time when unskilled workers become more qualified in using technology, so in the long run their wages level will increase, therefore the income inequality will be worsen with the inflow of foreign direct investment, but as time passes it would be improved (Figini \& Görg, 1999).Moreover, foreign direct investment affected negatively in manufacturing sector regarding to labor costs and skills. While it was affected relatively in services sector (Brandl, Strohmer, \& Traxler, 2013). From the firm perspective the decision to go to make investments or not outside is a controversial decision. meanwhile, those



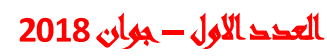






firms should take in consider the risks and benefits. Thereby the decision of accepting or rejecting foreign direct investment must be taken on the basis of short and long term macroeconomic variables and environmental factors. In the study of (Cambazoğlu \& Güneş, 2016) they found that foreign exchange levels was significantly affected by direct investment inflows in long term. in the study where many factors investigated, there were positive effect of foreign direct investment in GDP, but the negative effect was in real exchange rates, foreign trade deficit, and labor costs (Yaprakli, 2006). Another study composed of two countries having strong economic relationship one of them industrialized and technologically advanced which is the source of foreign direct investment, the second is the host country, which is developing and heavily dependent on the source. In the context of this study foreign direct investment has a strong influence on the economic growth of the developing country (Volos, Kyprianidis, \& Stouboulos, 2015). However, other studies tried to find the effect of foreign direct investment on technology investment or technology transferring. Further, investing in information and communication technology through foreign direct investment is revived innovative capabilities of host countries (Leitão \& Baptista, 2011). Furthermore, (Xu \& Sheng, 2012) found that foreign direct investment helping in technology diffusion which it affects productivity growth. Regarding to (Tahat \& Whelan, 2014) study which applied in GCC, indicated that the contribution level of foreign direct investment in technology diffusion is a worthy debate issue. relying on above mentioned literature, we will point out that if the foreign direct investment has an effect on the diffusion of information and communication technology. Therefore, in our study we will focus on four variables are: high-technology exports, information and communication technology (ICT) goods exports, information and communication technology (ICT) goods imports, and information and communication technology service exports. According to word bank those variables are defined as follows:



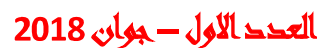




\begin{tabular}{|l|l|}
\hline \multicolumn{1}{|c|}{ The Effect of Foreign Direct Investment in Information and Communication } \\
Technology in Developing Countries The Case of Sultanate of Oman \\
Pr. Mansour Naser ALRAA
\end{tabular}

\section{Research Hypotheses}

Relying on the adopted constructs the researchers proposed the following hypotheses:

H1: High level of foreign direct investment has positive effect on High-technology exports.

H2: High level of foreign direct investment has positive effect on information and communication technology goods exports.

H3: High level of foreign direct investment has positive effect on information and communication technology goods imports.

H4: High level of foreign direct investment has positive effect on information and communication technology service exports.

\section{Research Model}

According to literature review and to the available statistics of the World Bank, the researches proposed the following research model that reflects the above hypotheses

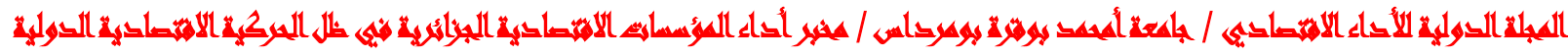
العتى الاول - ميوان 2018
} 


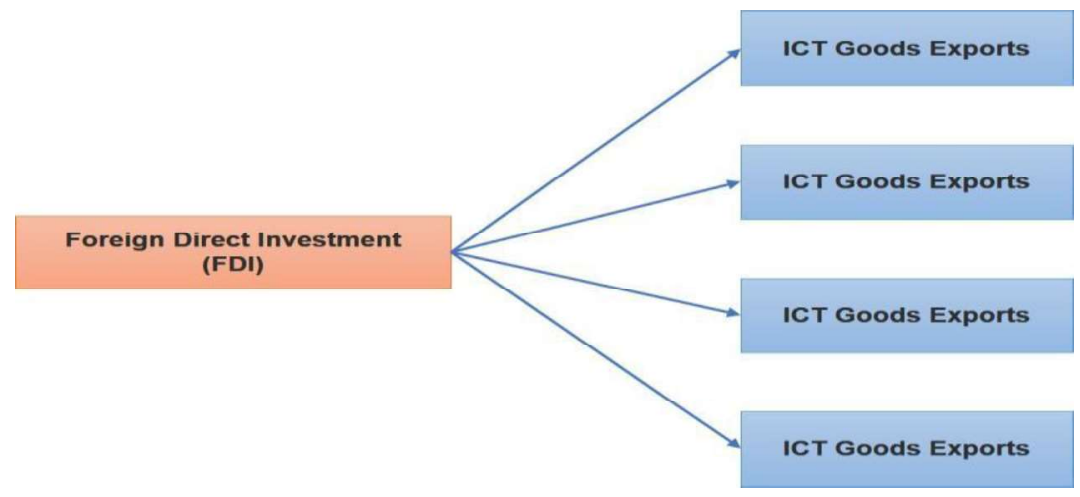

Research Model (Proposed by the authors)

This study contributes to the literature by being the first study that demonstrate the role of FDI on IT exports and imports in Oman.

\section{Research Methodology and Data Gathering}

This paper explores the relationship between foreign direct investment (FDI) and the IT exports and imports of Oman. In order to test the research hypotheses and reach the research goals; data was obtainedfromthe statistical data published by World Bank 2016.

Based on an extensive review of literature, data includes;statistical data about Oman on direct foreign investment and Omani IT exports were collected from 2000-2014.

Descriptive statistics for each of the study variables are provided in table 1 the authors present the means for the sample of domestic firms, standard deviation, median, minimum and maximum.

Simple regression model is used to analyze the data andtest the hypotheses of the study. The dependent variable is the foreign direct investment (FDI), and the independent variables are: Hightechnology exports, ICT goods exports, ICT goods imports and ICT service exports which are classified according to the World Bank.

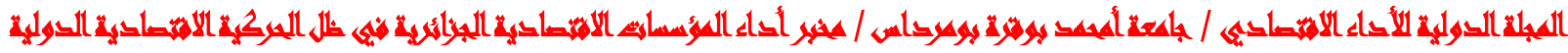

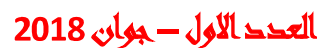




\section{Descriptive Analysis}

\begin{tabular}{|c|l|l|l|l|l|}
\hline \multicolumn{7}{|c|}{ Table 1 shows the results of descriptive statistics of the study variables } \\
\hline & $\begin{array}{c}\text { Foreign Direct Investment } \\
\text { FDI }\end{array}$ & $\begin{array}{c}\text { High- } \\
\text { Technology } \\
\text { Exports. }\end{array}$ & $\begin{array}{c}\text { ICT Goods } \\
\text { Imports }\end{array}$ & $\begin{array}{c}\text { ICT Service } \\
\text { Exports }\end{array}$ & $\begin{array}{c}\text { ICT Goods } \\
\text { Exports }\end{array}$ \\
\hline Mean & 1117188538.494 & 2.079836 & 3.419202 & 24.124702 & .272773 \\
\hline Median & 1039791937.99 & 2.167211 & 3.010750 & 22.271967 & .273734 \\
\hline Std. Deviation & 1029108862.322 & 1.7461475 & 1.0147710 & 7.8448530 & .1592491 \\
\hline Minimum & 5201560.4680 & .2754 & 2.1634 & 15.2412 & .0858 \\
\hline Maximum & 3332119636.00 & 5.7428 & 5.0629 & 38.0216 & .6011 \\
\hline
\end{tabular}

From the table above we can see that mean for high-technology exports, ICT goods imports, ICT service exports and ICT goods exports 2.07, 3.4, 24.12 and 0.272 respectively. While the value of standard deviation of the variables are $1.74,1.014,7.84$ and 0.15 respectively which can be interpreted that ICT service exports has the highest variations among study variables within the study period from 2000 until 2014.

\section{Regression Analysis and Hypothesis Testing}

Table 2 provides the results of regression analysis of the effect of foreign direct investment on high technology exports, the results show that beta value is -9.318 at 5 percent significant level which means there is a negative statistically effect for of foreign direct investment in sultanate of Oman on high technology exports. The value of $\mathrm{R}$ square indicates that 30.2 percent in high technology exports variation explained by this model, Also the value of Ftest is significant at 5 percent level which can be interpreted that the R-squared value is significantly explained 30.2 percent. Therefore, we reject the first hypothesis that says that high level of foreign direct investment has positive effect on Hightechnology exports,so it can be concluded that no existence of any relationship is and ad-hoc planning is the cause of these results.

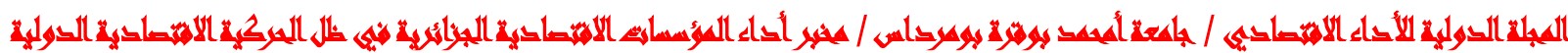

$$
2018 \text { العقى الاول - ميران }
$$


Table2: regression results between foreign direct investment and high technology exports

\begin{tabular}{|c|c|c|}
\hline & Value & Significant Level \\
\hline Constant & 3.121 & 0.000 \\
\hline Beta & -9.318 & 0.034 \\
\hline F test & 5.612 & 0.034 \\
\hline R square & 0.302 & \\
\hline
\end{tabular}

Table 3below shows the results of regression analysis for effect of foreign direct investment on ICT goods exports, thevalue of beta is -7.17 at 10 percent significant level which means there is a negative statistically effect for of foreign direct investment in sultanate of Oman on ICT goods exports. The R squarevalue indicates that 22.8 percent in ICT goods exportsvariation explained by this model, likewise, the value of Ftest is significant at 10 percent level which can be interpreted that the R-squared value is significantly explained 22.8 percent. Therefore, we reject the second Hypothesis that says that high level of foreign direct investment has positive effect oninformation and communication technology goods exports, so it can be concluded that no existence of any relationship is and ad-hoc planning is the cause of these results.

Table 3: regression results between foreign direct investment and ICT goods exports

\begin{tabular}{|c|c|c|}
\hline & Value & Significant Level \\
\hline Constant & 0.335 & 0.000 \\
\hline Beta & -7.17 & 0.084 \\
\hline F test & 3.551 & 0.084 \\
\hline R square & 0.228 & \\
\hline
\end{tabular}

Table 4displaysregressionresults for effect of foreign direct investment on high technology exports, the beta value is -5.98at 5 percent significant level which concludes there is a negative statistically effect for of foreign direct investment in sultanate of Oman on ICT goods imports. The value of $R$ squaredeterminethat 36.8 percent in ICT goods importsvariation explained by foreign direct investment, in addition to that, the value of $\mathrm{F}$ test is significant at 1 percent level which can be interpreted that the Rsquared value is significantly explained 36.8 percent. Consequently, we reject the third Hypothesis that says that High level of foreign direct investment has positive effect on information and communication technologygoods imports, so it can be concluded that no existence of any relationship is and ad-hoc planning is the cause of these results.


العقى الأول - يجان 2018 
Table4: regression results between foreign direct investment and ICT goods imports

\begin{tabular}{|c|c|c|}
\hline & Value & Significant Level \\
\hline Constant & 4.087 & 0.000 \\
\hline Beta & -5.98 & 0.017 \\
\hline F test & 7.557 & 0.017 \\
\hline R square & 0.368 & \\
\hline
\end{tabular}

The results of regression analysis for effect of foreign direct investment on ICT service exports are listed in the table 5, the results show that beta value is 6.65 at 5 percent significant level So, we can say that there is a positive statistically effect for of foreign direct investment in sultanate of Oman on ICT service exports. on the other hand, The R square value determines that 52.4 percent in ICT service exportsvariation explained by change in foreign direct investment, Also the value of Ftest is significant at 5 percent level which can be interpreted that the R-squared value is significantly explained 36.8 percent. So, we accept the forth Hypothesis that says that High level of foreign direct investment has positive effect oninformation and communication technologyservice exports, and this is the only positive conclusion of the listed above and one of the examples of this is Omantel that is exporting its services to several parties outside Oman.

\section{ICT Service Exports $=13.178+6.665 *$ FDI}

Table5: regression results between foreign direct investment and ICT service exports

\begin{tabular}{|c|c|c|}
\hline & Value & Significant Level \\
\hline Constant & 13.178 & 0.012 \\
\hline Beta & 6.665 & 0.018 \\
\hline F test & 8.816 & 0.018 \\
\hline R square & 0.524 & \multicolumn{1}{|}{} \\
\hline
\end{tabular}

\section{Limitations}

Several limitations were existed during this study, firstly; there are no official statistics available according to the classifications of the World Bank and the only source of statistics is the World Bank. Secondly; the researchers faced lack of updated or historical statistics as there is no available statistics (before 2000 or after 2014) during conducting this study. Thirdly; the study was applied only in Oman and it should empirically be being applied also on different developing countries in several continents in Asia, South of America and Africa.

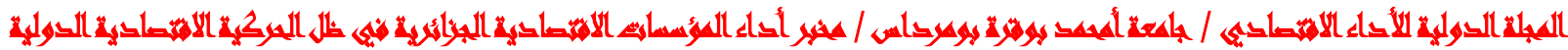
2018 العقى الاول - ميران 


\section{Conclusions}

This study empirically examines the effect of foreign direct investment in information and communication technology in Sultanate of Oman from 2000 to 2014 by using simple regression analysis model. The results show thatforeign direct investment (FDI) does not have effect on the hightechnology exports, information and communication technology goods exports and information and communication technology goods imports. While the study finds a positive and significant effectof foreign direct investment on information and communication technology service exports. Therefore, the study concludes that there is ad hoc planning for foreign direct investment planning in information and communication technology.

\section{References}

Alam, A. (2013). Electric power consumption, foreign direct investment and economic growth: A comparative study of India and Pakistan. World Journal of Science, Technology and Sustainable Development, 10(1), 55 - 65.

Blomström, M., \& Sjöholm, F. (1999). Technology transfer and spillovers: does local participation with multinationals matter? European economic review, 43(4), 915-923.

Brandl, B., Strohmer, S., \& Traxler, F. (2013). Foreign direct investment, labour relations and sector effects: US investment outflows to Europe. The International Journal of Human Resource Management, 34(17), 3281-3304.

Cambazoğlu, B., \& Güneş, S. (2016). The Relationship Between Foreign Exchange Rate and Foreign Direct Investment in Turkey. Economics, Management, and Financial Markets, 11(1), 284-293.

Campos, N., \& Kinoshita, Y. (2002). Foreign direct investment as technology transferred: Some panel evidence from the transition economies. The Manchester School, 70(3), 398-419.

Chaudhry, N. I., Mehmood, A., \& Mehmood, M. S. (2013). Empirical relationship between foreign direct investment and economic growth: An ARDL cointegration approach for China. China Finance Review International, 3(1), 26 - 41.

Demir, F., \& Su, L. (2016). Total Factor Productivity, Foreign Direct Investment, and Entry Barriers in the Chinese Automotive Industry. Emerging Markets Finance \& Trade, 52: 52(2), 302-321.

Farrell, D. (2004). The Case for Globalization The results of McKinsey's latest study of the pros

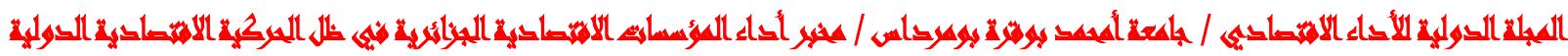

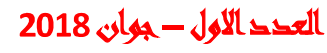


The Effect of Foreign Direct Investment in Information and Communication Technology in Developing Countries The Case of Sultanate of Oman

Pr. Mansour Naser ALRAJA

and cons of emerging market foreign investment. International Economy, 18(1), 52-55.

Figini , P., \& Görg, H. (2011). Does Foreign Direct Investment Affect Wage Inequality? An Empirical Investigation. The World Economy, 34(9), 1455-75.

Figini, P., \& Görg, H. (1999). Multinational Companies and Wage Inequality in the Host Country: The Case of Ireland. Weltwirtschaftliches Archive, 135 (4), 594-612.

Gulde, M., Kähkönen, M., \& Keller, M. (2000). Pros and cons of currency board arrangements in the lead-up to EU accession and participation in the euro zone (No. 0-1). International Monetary Fund.

IMF. (2012). Republic of Croatia: Selected Issues. Washington, DC.: International Monetary Fund.

Leitão, J., \& Baptista, R. (2011). Inward FDI and ICT: are they a joint technological driver of entrepreneurship? International Journal of Technology Transfer \& Commercialisation, 10 (3/4), 268-288.

Mah, J. S. (2015). The Effect of Foreign Direct Investment Inflows on Income Inequality: Evidence from China. Global Economy Journal , 15(4), 443-453. doi:DOI 10.1515/gej- 2015-0045

Mishal, Z., \& Abulaila, Z. (2007). The Impact of Foreign Direct Investment and Imports on Economic Growth: The Case of Jordan. Journal of Economic and Administrative Sciences, 23 (1), 1 - 31.

Srinivasan, P., Kalaivani, M., \& Ibrahim, P. (2011). An empirical investigation of foreign direct investment and economic growth in SAARC nations. ournal of Asia Business Studies, 5(2), 232 - 248.

Tahat , K., \& Whelan, S. (2014). A research proposal for investigating the effect of foreign direct investments on technology transfer in the Arabian Gulf (GCC). International Conference of integrated Information (IC-ININFO 2014) (pp. 193-198). Madrid, Spain: AIP Conf. Proc. 1644, 193(2015).

Volos, C. K., Kyprianidis, I. M., \& Stouboulos, I. N. (2015). The Effect of Foreign Direct Investment in Economic Growth from the Perspective of Nonlinear Dynamics. Journal of Engineering Science and Technology Review, 8(1), 1 -7.

Vukšić, G. (2016). Effects of Private Ownership, Trade, and Foreign Direct Investment on Labor Productivity Growth in Transition Economies: Evidence from the Croatian Manufacturing Industry. Emerging Markets Finance \& Trade, 52(2), 322-335. doi:10.1080/1540496X.2015.1011540

Xu, X., \& Sheng, Y. (2012). Productivity Spillovers from Foreign Direct Investment: Firm-Level Evidence from China. World Development, 40(1), 62-74. doi:doi:10.1016/j.worlddev.2011.05.006

Yaprakli, S. (2006). Türkiye'de Doðrudan Yabancý Yatýrýmlarýn Ekonomik Belirleyicileri Üzerine Ekonometrik Bir Analiz (An Econometric Analysis on the Economic Determinants of Foreign Direct Investments in Turkey). D.E.Ü. Ý.Ý.B.F. Dergisi, 21(2), 23-48.

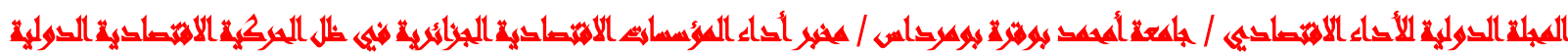

$$
2018 \text { العقى الاول - مئران }
$$

